OPEN ACCESS

Edited by:

Richard Eugene Frye, University of Arkansas for Medical

Sciences, United States

Reviewed by:

Sarah S. Knox,

West Virginia University,

United States

Shahanawaz Syed,

JSS College of Physiotherapy, India

*Correspondence:

Hsiang-Han Huang

hsianghan@mail.cgu.edu.tw

Specialty section:

This article was submitted to Child Health and Human

Development, a section of the journal

Frontiers in Pediatrics

Received: 24 August 2017 Accepted: 04 October 2017

Published: 25 October 2017

Citation:

Huang H-H, Sun T-H, Lin C-I and Chen Y-R (2017) Contextual Factors

and Mastery Motivation in Young

Children with and without Cerebral

Palsy: A Systematic Review.

Front. Pediatr. 5:224.

doi: 10.3389/fped.2017.00224

\section{Contextual Factors and Mastery Motivation in Young Children with and without Cerebral Palsy: A Systematic Review}

\author{
Hsiang-Han Huang ${ }^{1,2 *}$, Tzu-Han Sun ${ }^{3}$, Chia-I Lin ${ }^{3}$ and Yi-Ru Chen ${ }^{3}$ \\ ${ }^{1}$ Department of Occupational Therapy, Graduate Institute of Behavioral Sciences, Chang Gung University, Taoyuan, Taiwan, \\ 2 Joint Appointment with Department of Physical Medicine and Rehabilitation, Chang Gung Memorial Hospital, Linkou, \\ Taiwan, ${ }^{3}$ Department of Occupational Therapy, Chang Gung University, Taoyuan, Taiwan
}

Background: Mastery motivation is the driving force behind children's desire to explore the surrounding world and their comprehensive development. However, disease factors may lower a child's motivation and hamper development. The aim of this review is to examine mastery motivation in preschool children with cerebral palsy (CP) and the impact of contextual factors on mastery motivation.

Methods: Six electronic databases were searched (PubMed, ScienceDirect, Scopus, PsycINFO, Medline, and Airiti Library) using the keywords "Activity," "Cerebral Palsy," "Preschool," "Motivation," "Mastery motivation," "Gross motor," and "Toddller." We reviewed six observational studies and one interventional study for the following features: (1) participants' characteristics; (2) assessment, observation, and intervention methods; (3) findings.

Results: Of the seven studies, three were individual cohort studies and four were individual case-control studies. There were two types of motivation-related measures, standardized measurements and observations of structured tasks or free play. Three studies showed no significant difference in mastery motivation between children with and those without CP when given mental-age-appropriate tasks of moderate difficulty. However, environmental factors including social experience, family interaction, and caregivers' perceptions may affect motivation in preschool children with CP.

Conclusion: Current studies on mastery motivation in preschool children with CP are very limited, and the lack of a universal, theory-based definition of mastery motivation and common assessment frameworks makes it difficult to draw clear conclusions on mastery motivation in children with CP. Future studies should investigate mastery motivation with rigorous study designs to identify ideal activities and environments for preschool children with CP.

Keywords: mastery motivation, contextual factors, preschool, cerebral palsy, child development

\section{INTRODUCTION}

Motivation is classified as a mental function which belongs to the body function level in the International Classification of Functioning, Disability, and Health (ICF) (1). As an intrinsic function, mastery motivation enables an individual to autonomously and consistently perform and enjoy activities with moderate difficulty $(2,3)$. The ICF model emphasizes the dynamic 
reciprocal relations among functional levels (body function/ structure, activity, and participation) and contextual factors (personal and environmental) (1,4). Mastery motivation, as a function of the body, can not only influence children's behaviors and performances in both family and educational spheres, but can also increase or decrease as mediated by environmental and personal factors such as family support and age $(5,6)$. It plays an important role in learning new skills, adapting to new environments, and developing self-efficacy during child development (7). Specifically, studies have found that young children's developmental abilities are positively correlated with mastery motivation, including toddlers and preschoolers with typical development (TD) $(3,8)$. Other contextual factors, e.g., the interaction of young children with their primary caregivers, access to objects and materials, age, and gender, may all have effects on children's mastery motivation $(2,9)$.

The two primary subtypes of mastery motivation are object (i.e., instrumental) mastery motivation and social (i.e., expressive) mastery motivation $(2,10)$. The former is represented by persistence and the duration of goal-directed behaviors; the latter refers to enjoyment during or after goal-directed behaviors. Previous studies show that both subtypes of mastery motivation can be investigated with standardized questionnaires, challenging structured tasks, and free play observation $(5,8,9)$. They have found mastery motivation emerging in late infancy as a precursor to self-determination, setting a course of increased independence and an enhanced perception of the ability to control one's environment (2). Starting from the toddler age, the development of mastery motivation is predictable in young children with TD $(2,8)$. Higher levels of mastery motivation are observed in early life, better developmental outcomes are observed in preschool children with TD. However, disease factors can lower a child's motivation and subsequently hamper overall development. Cerebral palsy (CP) is one such disease causing motor, cognitive, and sensory disabilities. Global population-based studies estimate that prevalence of CP ranges from 1.5 to more than 4 per 1,000 live births or 1,000 children of a defined age range (11-14). According to the ICF framework, compared with preschool children with TD, preschoolers with $\mathrm{CP}$ have poorer health and variable body structures and functions.

Increasing children's motivation to improve their performance and seek pleasure in activities and participation can be considered a form of intervention, specifically for young children with CP. Current strategies of early intervention mostly utilize top-down approaches and ecological theories to promote the individual's body functions and health status, e.g., context or function therapy and the application of virtual reality technologies (15-18). These therapies use daily activities as the key intervention, emphasizing motivation of young children with $\mathrm{CP}$ to participate in the treatment and then tasking them with functional performances (19). Although targeted standardized tests and assessments of motivation have not been applied in these studies, from a theoretical perspective, the effects of therapy and health status itself would be enhanced if motivation-promoting factors (including autonomy, continuity, and pleasure) were promoted, and environmental and personal factors were considered in children's activities (3).
The aim of this study is to examine mastery motivation in preschool children with $\mathrm{CP}$ and the impact of contextual factors on mastery motivation. A systematic review was conducted to investigate motivation and relevant interventions for preschool children with CP to answer the following questions: Are there differences in motivation between preschool children with and those without CP? Are there contextual factors that affect mastery motivation in children with $\mathrm{CP}$ ? The results of this review may provide guidelines for clinicians in developing interventions to improve therapeutic outcomes in preschool children with CP.

\section{METHODS}

We searched six electronic databases: PubMed (1966 through August 2017), ScienceDirect (1966 through August 2017), Scopus (1966 through August 2017), PsycINFO (1946 through August 2017), Medline (1966 through August 2017), and Airiti Library (1967 through August 2017), using the keywords "Activity," "Cerebral Palsy," "Preschool," "Motivation," "Mastery motivation," "Gross motor," and "Toddler." References from relevant publications were also included as appropriate. The following inclusion criteria were applied: (1) participants included preschool children with CP (aged under 5); (2) the study included an assessment tool for mastery motivation or detailed discussion on observed changes in motivation; (3) the study was published in a peer-reviewed journal either in English or in Chinese.

Figure 1 shows that 705 articles published till August 2017 were selected. Thirteen more articles were included from references associated with the research topic in this paper, resulting in a total of 718 articles. After title and abstract screening, 595 articles were excluded because the participants were not preschool age or the articles were not peer-reviewed ones. In addition, 74 articles did not provide detailed discussions on mastery motivation and 36 articles were not published in English or Chinese language. 13 articles were chosen by the abstract screening, 6 of which were further excluded after screening of the entire manuscript due to the lack of direct measurements of mastery motivation or because recruited participants were over 5 years of age. Thus, seven articles were included in the analysis. Six were observational studies to examine mastery motivation, and one focused on intervention to promote mastery motivation in children with $\mathrm{CP}$.

\section{RESULTS}

There was limited evidence regarding mastery motivation in preschool children with CP. Seven original studies met the criteria. Using the Oxford Centre for Evidence-Based Medicine's (OCEBM) levels of evidence classification system (20), the studies offered $2 \mathrm{~b}$ and $3 \mathrm{~b}$ levels of evidence (Table 1). Of the seven original studies, three were individual cohort studies (level 2b) and four were individual case-control studies (level 3b). The following features were documented for each study: (1) characteristics of the participants; (2) the assessments and methods of observation or intervention; and (3) findings (Table 2). In the following sections, we have described how these specific features 


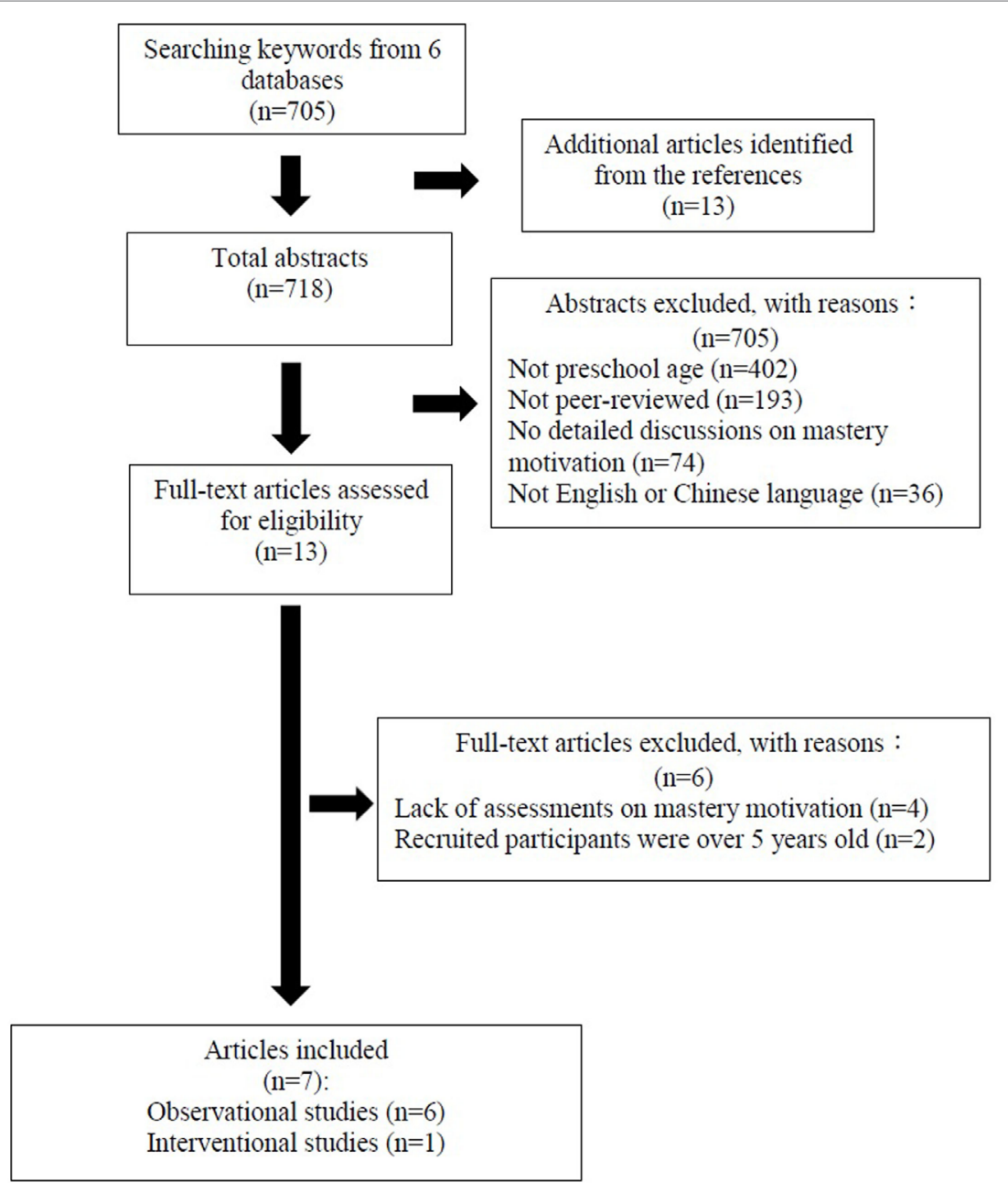

FIGURE 1 | Flow chart of the search results.

were presented in each study and organized relevant information to elucidate on motivation interventions in preschool children with CP.

\section{Characteristics of Participants}

The number of participants ranged from 19 to 69 children at different levels of study (Table 2). Altogether, 255 children aged 9-53 months were included. Eighty-eight (34.5\%) children had CP; the remaining 167 had TD, spina bifida, developmental delay, brain injury, and other comorbidities. Six studies required that the participants had developed normal or certain cognitive criteria. For instance, some studies stipulated that children's mental age be above a certain month $(7,21,22)$ or IQ be above $70(23,24)$, or that children display no moderate-to-severe cognitive disability (25). Two observational studies included the Comprehensive Developmental Inventory for Infants and Toddlers (CDIIT) to identify children with movement disorders scoring under 85 $(7,22)$. The rationale for the cognitive or motor criteria may have been based on the need for each child to perform the structured tasks of motivation tests (9).

\section{Assessments and Methods of Observation or Intervention}

In the seven observational or interventional studies, there were two major types of motivation-related measures, including standardized measurements and observations of structured tasks or free play (Table 3). Standardized measurements included the assessment tool and parents' questionnaire $(7,22,24,25)$, while observation involved applications of structured tasks with defined psychometric properties $(7,21-24,26)$. Three studies used both methods, one used a standardized measurement or questionnaire only, and three used observation only (by an independent person) (Table 3). The standardized measurements included Individualized Assessment of Mastery Motivation, Mother's Observation of Mastery Motivation (questionnaire), and Dimensions of Mastery Questionnaire. Observations referred to the participants' performances in completing the structured tasks or during the school free play time and focused on persistence and pleasure. These methods can be used jointly for measuring motivation to provide objective and comprehensive data. 
TABLE 1 | Level of evidence of studies.

\begin{tabular}{|c|c|c|c|c|}
\hline $\begin{array}{l}\text { Grade of } \\
\text { recommendation }\end{array}$ & $\begin{array}{l}\text { Level of } \\
\text { evidence }\end{array}$ & Descriptions & $\begin{array}{l}\text { Number } \\
\text { of studies }\end{array}$ & Citations \\
\hline \multirow[t]{3}{*}{ A } & $1 \mathrm{a}$ & Systematic reviews (with homogeneity) of randomized controlled trials & None & \\
\hline & $1 b$ & Individual randomized controlled trials (with narrow confidence interval) & None & \\
\hline & $1 c$ & All or none randomized controlled trials & None & \\
\hline \multirow[t]{5}{*}{ B } & $2 a$ & Systematic reviews (with homogeneity) of cohort studies & None & \\
\hline & $2 b$ & Individual cohort study or low quality randomized controlled trials (e.g., <80\% follow-up) & 3 & $\begin{array}{l}\text { Jennings et al. (1988) (23), } \\
\text { Waldman-Levi et al. (2015) } \\
\text { (25), and Medeiros et al. } \\
\text { (2016) (26) }\end{array}$ \\
\hline & $2 \mathrm{c}$ & "Outcomes" Research; ecological studies & None & \\
\hline & $3 a$ & Systematic review (with homogeneity) of case-control studies & None & \\
\hline & $3 b$ & Individual case-control study & 4 & $\begin{array}{l}\text { Jennings et al. (1985) (24), } \\
\text { Hauser-Cram (1996) (21), } \\
\text { Wang et al. (2013) (7), and } \\
\text { Wang et al. (2014) (22) }\end{array}$ \\
\hline C & 4 & Case-series (and poor quality cohort and case-control studies) & None & \\
\hline D & 5 & $\begin{array}{l}\text { Expert opinion without explicit critical appraisal, or based on physiology, bench research or } \\
\text { "first principles" }\end{array}$ & None & \\
\hline
\end{tabular}

Levels of evidence are based on the levels of evidence and grades of recommendations from Oxford Centre for Evidence-Based Medicine (20).

$R C T$, randomized controlled trial.

Some studies reported detailed observations of the following: positive emotions during activities (such as competence, pleasure, interest, and self-efficacy), duration of activities, initiation of participation, willingness to participate in activities, and length of children's attention maintained during an activity. These indices are included in the definition of mastery motivation (10). In addition, in two studies, assessments of children's curiosity during activities and interactions with parents during activities were also considered $(23,24)$. In six observational studies, the children were asked to conduct structured tasks or carry out free play with the therapist or researcher observing their interactions with parents $(7,21,22,26)$ or peers $(23,24)$. The only motivation-related interventional study aimed to modify the social and physical environments to enhance children's mastery motivation (25). The interventions were based on the guidelines described in the Early Childhood Environment Rating Scale-Revised (ECERS-R) for improved environments and included furniture and space arrangement, creation of quiet area and interest areas, room arrangement facilitating children's autonomy, free play and child's independence, verbal mediation, and verbal reinforcement.

\section{Research Findings}

Factors influencing motivation for preschool children with $\mathrm{CP}$ were discussed in five observational studies and compared with those influencing children with TD (Tables 2 and 3). Specifically, two of them reported that preschool children with disabilities tended to show less mastery motivation and persistence on tasks than children with TD while interacting with peers, but intellectual functioning was independent of mastery motivation $(23,24)$. However, as reported by Hauser-Cram (21), cognitive functions can affect the level of motivation in children with CP. Three studies showed that there was no significant difference in mastery motivation between children with atypical development and TD while interacting with parents $(7,21,22)$. In addition, studies indicated that several factors associated with physical impairments, social play, degree of prematurity, history of a seizure disorder, maternal didactic interaction, and caregivers' perceptions of children's motivation may influence preschooler's mastery motivation $(7,21-23,26)$. Jennings et al. (23) reported that motivation of preschool children increased with age; however, social experience, which varied with different cognition degrees, significantly contributed to the development of motivation. The findings of the five studies relating to the observations during structured or free play indicated the social experience from the interaction with parents or peers might result in different effects on mastery motivation $(7,21-24,26)$; the positive interaction between parents and the child might promote his/her mastery motivation which is similar to the child with TD. Wang et al. $(7,22)$ also reported that if children with and those without developmental delay were assigned tasks corresponding to their mental age and with moderate difficulty, their motivation for mastery was the same. Task difficulty was a crucial factor in motivation assessment. In addition, caregivers' perceptions and interaction styles also greatly influenced children's motivation. One study compared different modes of interaction between mothers and children and concluded that didactic interactions could promote children's motivation (21). Another pointed out that children with $\mathrm{CP}$ were likely to be overly dependent on their caretakers, which was detrimental to the development of motivation (24).

In terms of intervention, Waldman-Levi and Erez (25) reported that a combination of physical and social modifications may be the best way to improve mastery motivation in children with $\mathrm{CP}$, although the social environment modifications appeared to have a greater effect than the physical environment modifications. Moreover, they found that encouraging, supportive, and sensitive caregivers played an important role in promoting children's mastery motivation in the initial phase of treatment planning. 
TABLE 2 | Summary of studies

\begin{tabular}{|c|c|c|c|c|c|c|c|}
\hline $\begin{array}{l}\text { Level of } \\
\text { evidence }\end{array}$ & Citations & Study design & Purpose & Participants & Ages (years) & Observation/intervention & Findings \\
\hline $2 b$ & $\begin{array}{l}\text { Jennings } \\
\text { et al. (1988) } \\
\text { (23) }\end{array}$ & $\begin{array}{l}\text { Observational/ } \\
\text { cohort with } \\
\text { concurrent } \\
\text { group }\end{array}$ & $\begin{array}{l}\text { (a) To examine the } \\
\text { mastery motivation } \\
\text { in children with and } \\
\text { without physical } \\
\text { impairments at both } \\
3.5 \text { and } 4.5 \text { years of } \\
\text { age } \\
\text { (b) To assess children's } \\
\text { IQ and socioeconomic } \\
\text { background to } \\
\text { determine equivalence } \\
\text { of the two groups of } \\
\text { children } \\
\text { (c) To examine the } \\
\text { relationship between } \\
\text { the severity level of } \\
\text { impairments and } \\
\text { mastery motivation }\end{array}$ & $\begin{array}{l}\text { Total: } 61 \text { children } \\
\text { with }(n=22) \text { and } \\
\text { without physical } \\
\text { impairments }(n=39) \\
\text { (CP: } n=12)\end{array}$ & $\begin{array}{l}\text { Mean age: the first } \\
\text { assessment-children with } \\
\text { ( } 47 \text { months) and without } \\
\text { physical impairments } \\
\text { ( } 46 \text { months) } \\
\text { The second assessment- } \\
\text { children with (59 months) } \\
\text { and without physical } \\
\text { impairments ( } 58 \text { months) }\end{array}$ & $\begin{array}{l}\text { Structured tasks to assess } \\
\text { mastery motivation were } \\
\text { administered at school, } \\
\text { followed about } 2 \text { weeks later by } \\
\text { McCarthy Scales of Children's } \\
\text { Abilities. Free play was also } \\
\text { observed during this period. } \\
\text { The severity level of impairments } \\
\text { was rated by the examiners. }\end{array}$ & $\begin{array}{l}\text { 1. Children with TD generally showed more mastery } \\
\text { motivation during both structured tasks and free } \\
\text { play than their peers with physical impairments. } \\
\text { However, there was no significant difference on } \\
\text { curiosity. } \\
\text { 2. Children with TD persisted more on difficult tasks } \\
\text { and more frequently chose challenging tasks over } \\
\text { easy tasks. Their activities lasted longer during } \\
\text { play and were more complex and cognitively } \\
\text { mature; they also spent less tie unfocused. } \\
\text { 3. The severity level of impairments showed little } \\
\text { relation to motivation. Differences in motivation } \\
\text { between these children with TD and physical } \\
\text { impairments could be attributed to differences } \\
\text { in experiences associated with being physically } \\
\text { impairments. }\end{array}$ \\
\hline $2 b$ & $\begin{array}{l}\text { Waldman- } \\
\text { Levi and Erez } \\
\text { (2015) (25) }\end{array}$ & $\begin{array}{l}\text { Intervention/ } \\
\text { cohort with } \\
\text { concurrent } \\
\text { control group }\end{array}$ & $\begin{array}{l}\text { To examine the efficiency } \\
\text { of an intervention } \\
\text { program for children with } \\
\text { developmental disabilities, } \\
\text { by modifying both their } \\
\text { social and physical } \\
\text { environments, in order } \\
\text { to enhance their mastery } \\
\text { motivation }\end{array}$ & $\begin{array}{l}\text { Total: } 19 \text { children } \\
\text { with developmental } \\
\text { disabilities are } \\
\text { assigned to } 2 \text { classes } \\
\text { (class A: } n=9 \text {; class } \\
\text { B: } n=10 \text { ) } \\
\text { (CP: } n=12 ; 6 \text { in } \\
\text { each class) }\end{array}$ & $\begin{array}{l}2 \text { to } 4 \\
\text { Mean age: Class } \\
\text { A-41.44 months; } \\
\text { Class B-33.8 months }\end{array}$ & $\begin{array}{l}\text { The two classes received two } \\
\text { phases of intervention, 6-week } \\
\text { social and 6-week physical } \\
\text { environmental interventions, in } \\
\text { an altering sequence. }\end{array}$ & $\begin{array}{l}\text { 1. The social environment modifications were } \\
\text { found to be effective in improving mastery } \\
\text { motivation. Moreover, it appeared to have greater } \\
\text { improvement than the physical environment } \\
\text { modifications. } \\
\text { 2. Having supportive, encouraging and sensitive } \\
\text { caregivers who promoted children's mastery } \\
\text { motivation was a necessary initial step in } \\
\text { treatment planning for these children }\end{array}$ \\
\hline $2 \mathrm{~b}$ & $\begin{array}{l}\text { Medeiros } \\
\text { et al. (2016) } \\
\text { (26) }\end{array}$ & $\begin{array}{l}\text { Observational/ } \\
\text { cohort }\end{array}$ & $\begin{array}{l}\text { To compare longitudinal } \\
\text { changes in mastery } \\
\text { motivation during parent- } \\
\text { child free play for } 37 \\
\text { children with complex } \\
\text { communication needs }\end{array}$ & $\begin{array}{l}\text { Total: } 37 \text { children } \\
\text { with complex } \\
\text { communication } \\
\text { needs } \\
(\mathrm{CP}: n=16)\end{array}$ & 9-27 months (CP) & $\begin{array}{l}\text { Unprompted parent-child play } \\
\text { episodes were identified in three } \\
\text { assessment sessions over an } \\
18 \text {-month period and coded } \\
\text { for } 9 \text { categories of mastery } \\
\text { motivation in social and object } \\
\text { play. }\end{array}$ & $\begin{array}{l}\text { 1. Measuring mastery motivation using social } \\
\text { categories such as anticipatory affect or } \\
\text { social referencing could provide a less biased } \\
\text { representation of mastery motivation for children } \\
\text { with relatively low receptive language skills. } \\
\text { 2. Low object-based mastery motivation scores } \\
\text { reported for children with developmental } \\
\text { disabilities may be a function of their impaired } \\
\text { motor skills rather than low levels of mastery } \\
\text { motivation itself. } \\
\text { 3. Encouraging partners to challenge children } \\
\text { during social play or adapt object play by adding } \\
\text { social elements may be an effective strategy for } \\
\text { building and maintaining child mastery motivation } \\
\text { in play interactions and reducing common risks } \\
\text { for passive interaction styles for children with } \\
\text { complex communication needs. }\end{array}$ \\
\hline
\end{tabular}




\begin{tabular}{|c|c|c|c|c|c|c|c|}
\hline $\begin{array}{l}\text { Level of } \\
\text { evidence }\end{array}$ & Citations & Study design & Purpose & Participants & Ages (years) & Observation/intervention & Findings \\
\hline $3 b$ & $\begin{array}{l}\text { Jennings } \\
\text { et al. (1985) } \\
\text { (24) }\end{array}$ & $\begin{array}{l}\text { Observational/ } \\
\text { case-control }\end{array}$ & $\begin{array}{l}\text { To compare the difference } \\
\text { on mastery motivation in } \\
\text { preschool children with } \\
\text { and without disabilities }\end{array}$ & $\begin{array}{l}69 \text { children with } \\
(n=25) \text { and without } \\
\text { disabilities }(N=44) \\
(\mathrm{CP}: n=15)\end{array}$ & $\begin{array}{l}36-53 \text { months (mean: } \\
3 \text { years } 10 \text { months) }\end{array}$ & $\begin{array}{l}\text { Motivation in both structured } \\
\text { (i.e., structured tasks) and } \\
\text { unstructured situations (i.e., } \\
\text { free play behavior at school) } \\
\text { was observed and assessed. } \\
\text { Mothers' perceptions of their } \\
\text { children's motivation were also } \\
\text { assessed. }\end{array}$ & $\begin{array}{l}\text { 1. Intellectual functioning (i.e., IQ) was independent } \\
\text { of mastery motivation in children with disabilities. } \\
\text { 2. During adult-structured activities, children with } \\
\text { disabilities tended to be less persistent on difficult } \\
\text { tasks. Moreover, their play during unstructured } \\
\text { activities was less complex and peer-oriented. } \\
\text { 3. Greater dependency on adults might be one } \\
\text { factor affecting the development of mastery } \\
\text { motivation in children with disabilities. } \\
\text { 4. Children with disabilities might benefit from more } \\
\text { unstructured times in which they could develop } \\
\text { their own resources and ideas. }\end{array}$ \\
\hline $3 b$ & $\begin{array}{l}\text { Hauser-Cram } \\
\text { (1996) (21) }\end{array}$ & $\begin{array}{l}\text { Observational/ } \\
\text { case-control }\end{array}$ & $\begin{array}{l}\text { (a) To examine the } \\
\text { differences on } \\
\text { mastery motivation } \\
\text { in children with } \\
\text { motor impairments, } \\
\text { developmental delay } \\
\text { and TD } \\
\text { (b) To investigate the } \\
\text { hypothesized relation } \\
\text { between maternal } \\
\text { didactic interaction } \\
\text { and mastery } \\
\text { motivation in children } \\
\text { with developmental } \\
\text { disabilities }\end{array}$ & $\begin{array}{l}\text { Total: } 25 \text { children } \\
\text { with typical cognitive } \\
\text { development; } 25 \\
\text { children with motor } \\
\text { impairment (CP) } \\
\text { and } 25 \text { children with } \\
\text { developmental delay, } \\
\text { matched for mental } \\
\text { age }\end{array}$ & $\begin{array}{l}\text { Mean age (months): } \\
\text { Motor impaired: } 23.4 \\
\text { Developmental delay: } \\
26.0 \\
\text { TD: } 16.8\end{array}$ & $\begin{array}{l}\text { A home visit was conducted to } \\
\text { assess children's developmental } \\
\text { scores and measure their } \\
\text { mastery motivation; mother-child } \\
\text { interaction was also observed } \\
\text { during a teaching task }\end{array}$ & $\begin{array}{l}\text { 1. Mastery motivation did not differ for young } \\
\text { children with delayed or atypical development } \\
\text { during sensorimotor period if they were } \\
\text { compared to children of a similar level of } \\
\text { development and were given tasks of similar } \\
\text { difficulty } \\
\text { 2. Degree of prematurity, history of a seizure } \\
\text { disorder, and maternal didactic interaction were } \\
\text { predictive of the measures of mastery motivation } \\
\text { in children with developmental disabilities. } \\
\text { 3. Children whose caregivers gave clear directions } \\
\text { and offered both verbal and nonverbal support } \\
\text { and praise when teaching them a task appeared } \\
\text { to be more motivated to persist with other } \\
\text { challenging tasks on their own. }\end{array}$ \\
\hline $3 b$ & $\begin{array}{l}\text { Wang et al. } \\
\text { (2013) (7) }\end{array}$ & $\begin{array}{l}\text { Observational/ } \\
\text { case-control }\end{array}$ & $\begin{array}{l}\text { (a) To investigate } \\
\text { differences between } \\
\text { toddlers with and } \\
\text { without MD, but } \\
\text { matched on mental } \\
\text { age and sex, on both } \\
\text { the instrumental and } \\
\text { expressive aspects } \\
\text { of mastery motivation } \\
\text { using both the } \\
\text { parent-completed } \\
\text { questionnaire and } \\
\text { behavioral task } \\
\text { methods }\end{array}$ & $\begin{array}{l}\text { Total: } 22 \text { toddlers } \\
\text { with } \mathrm{MD} ; 22 \text { age- } \\
\text { matched toddlers } \\
\text { with TD } \\
(\mathrm{CP}: n=4)\end{array}$ & $\begin{array}{l}24-48 \text { months } \\
\text { Mean age: Children with } \\
\text { MD: } 30.8 \text { months } \\
\text { Children with TD: } \\
21.0 \text { months }\end{array}$ & $\begin{array}{l}\text { Persistence and mastery } \\
\text { pleasure were measured with } \\
\text { behavioral tasks that were } \\
\text { moderately challenging for } \\
\text { each child and with maternal } \\
\text { ratings using DMQ. Two types of } \\
\text { structured tasks (a puzzle and a } \\
\text { cause-effect toy selected to be } \\
\text { moderately challenging for each } \\
\text { child) were administered in a } \\
\text { laboratory setting and recorded } \\
\text { on video. }\end{array}$ & $\begin{array}{l}\text { 1. The results indicated that the } 2 \text { measures } \\
\text { assessed different aspects of mastery motivation: } \\
\text { parental perception of motivation in everyday } \\
\text { life and observations of mastery behavior in a } \\
\text { structured setting. } \\
\text { 2. Toddlers with MD did not show lower persistence } \\
\text { and pleasure when given tasks that were } \\
\text { moderately challenging, in comparison with the } \\
\text { mental age-matched children with TD. } \\
\text { 3. Mothers of toddlers with MD tended to view their } \\
\text { children as having low motivation for mastering } \\
\text { difficult tasks. } \\
\text { 4. For parents' education, therapists can teach } \\
\text { the differences between ability and motivation } \\
\text { and the importance of mastery motivation for } \\
\text { development. }\end{array}$ \\
\hline
\end{tabular}

between maternal

and mastery

motivation in children

with developmental

Total: 25 children $\quad$ Mean age (months):

with typical cognitive Motor impaired: 23.4

development; 25

children with motor 26.0

and 25 children with

developmental delay,

matched for mental

age 


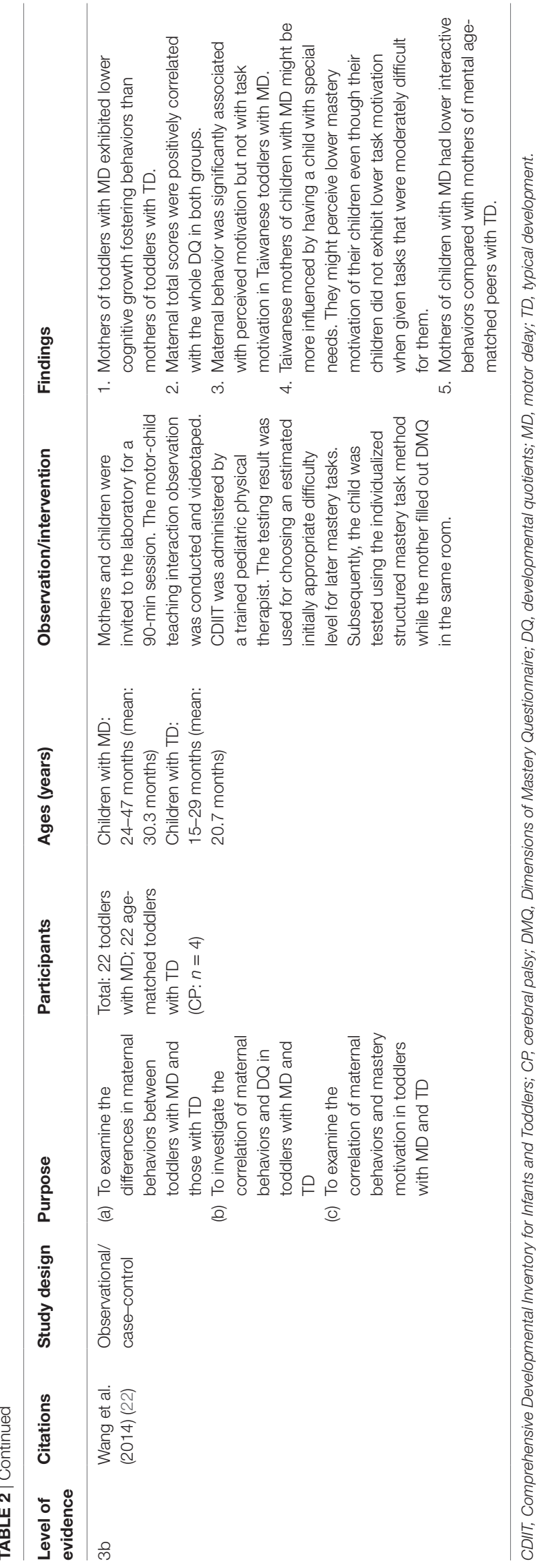

Overall, most observational studies found that preschool children with CP showed similar persistence and pleasure as children with TD. However, the studies identified several factors that may influence mastery motivation, including measures of motivation (i.e., object or social mastery motivation), task difficulty, parenting styles, caregivers' perceptions of children's mastery motivation related to cultural contexts, and children's experience of physical impairment. Relevant interventions focusing on modifying physical and social environments may be beneficial for improving both object and social mastery motivation in preschool children with CP.

\section{DISCUSSION}

To date, this is, to our knowledge, the first systematic review to examine and compare mastery motivation in preschool children with and those without $\mathrm{CP}$ and to provide evidence on motivation-related interventions in this particular pediatric population. The seven relevant studies we found show that there may be no significant difference in mastery motivation between children with and those without $\mathrm{CP}$ when administered tasks of moderate difficulty and suitable mental age. However, contextual factors, particularly environmental factors, including social experience, family mode of interaction, and caregivers' perceptions, can affect the level of motivation in preschool children with CP. Notably, there are few studies on preschool children's motivation, most of the available evidence is low-level-implying that the field of contextual factors and mastery motivation in young children with $\mathrm{CP}$ is under-researched-and large-scale rigorous research designs are scarce. Thus, future studies should focus on examination of these factors to provide more detailed information.

It remains unclear whether mastery motivation varies with cognitive functional level in preschool children with CP. The included studies had conflicting results; one study reported that cognitive function had no effect on motivation level (24), while another reported a contradictory result, while also reporting that differences in motivation of children with and those without developmental delay was negligible before the sensorimotor stage and only became significant afterward; however, this needs further explanation (21). Although both articles considered similar factors in their assessments, contrasting results were obtained, and no consistent conclusion was reached. This may be because early studies did not have a clear definition of motivation, and assessment methods used in the studies were different. Three studies proposed that children with and those without $\mathrm{CP}$ have similar motivation when administered tasks of moderate difficulty $(7,21,22)$. Therefore, the suitability of a task may be more important to motivation than cognitive functions (2).

Among studies reviewed here, assessment tools, including standardized tools, were often used in conjunction with observation by a third person, e.g., a therapist or a teacher, because of their objectivity and professionality. In studies involving observations by both parents and therapists, mothers were inclined to judge the motivation level by the level of competence in their children; for example, mothers of children with disabilities tended to think that their children had low motivation levels $(3,5)$. Parents may consider tasks too difficult for their children and underestimate 
their children's motivation in questionnaires; a disadvantage potentially limited by parents' perceptions of children's capabilities $(27,28)$. However, parental observation has advantages as well because it offers data on children's performances in a natural environment and reduces the cost and time of studies $(7,9)$. In summary, observations from both therapists and parents are recommended to further understand changes in motivation and influencing factors for preschool children. Before parents complete the questionnaires, therapists should educate them on the concept of motivation and the suitability of activities for their children $(7,29)$.

Toward operationalizing a definition of mastery motivation, studies included observation of persistence, attention span, curiosity, competence, pleasure, and positive and negative

TABLE 3 | Summary of studies: outcomes, measures, and results (those relating to cerebral palsy and motivation).

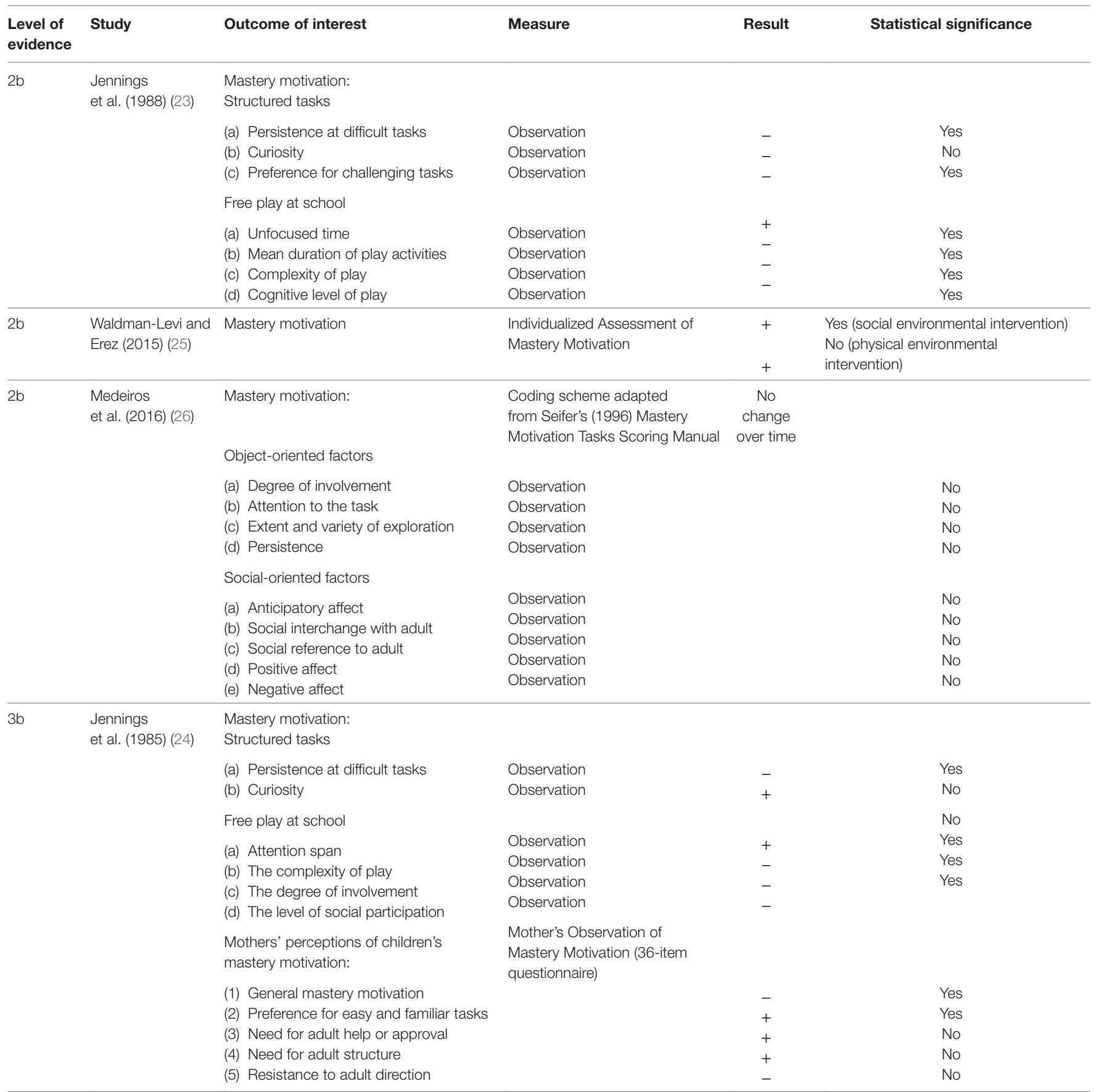


TABLE 3 | Continued

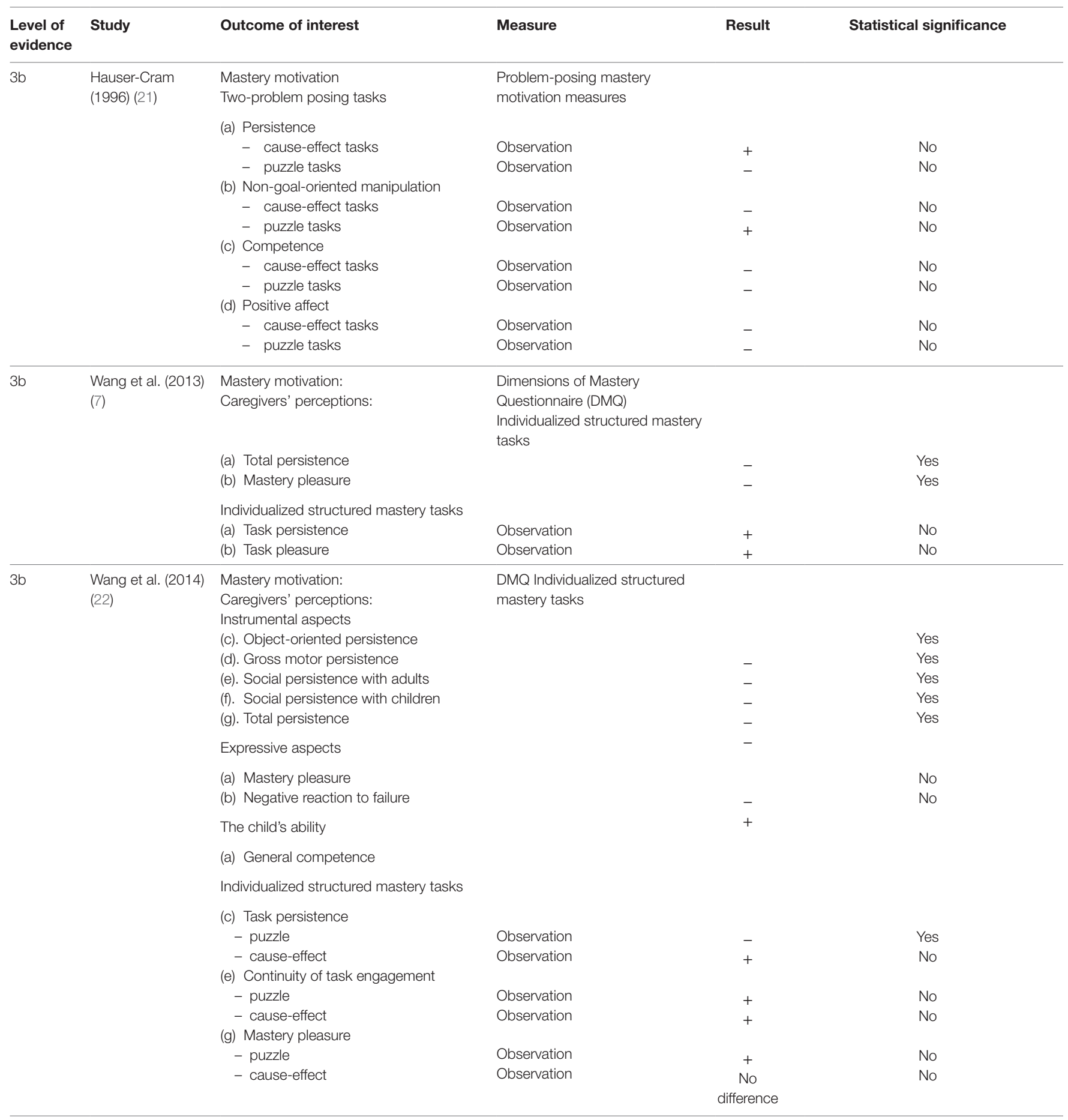

pleasure among their measures. Many studies mentioned the impact of motivation on overall development in children with $\mathrm{CP}$, specifically for upper and lower limb motor development $(17,18,30-32)$. However, there was a lack of shared definition of motivation and assessment tools to detect changes in motivation before and after an intervention. For instance, some studies emphasized improvements in children's performances but regarded the increase in movement frequency and function as indicators of motivation $(31,32)$. The studies employing virtual reality technologies also focused on the role of motivation in shaping motor outcomes $(17,18)$. These studies used standardized assessments to measure children's playfulness and the VR system to record children's drive to play and intensity of play during an intervention. This method may overlook the definition of mastery motivation and the challenging level of the games is mostly set up by the program, not according 
to the child abilities (33). Future studies will benefit from a standardized approach of measuring motivation, its relationship to environmental factors, and the impact of interventions. We suggest that developing such an approach is a priority for researchers and practitioners.

According to Turner and Johnson's (3) proposed model of mastery motivation, children with high mastery motivation will engage with toys, people, and events, and mastery motivation can be divided into object and social mastery motivation (2). Furthermore, parenting beliefs and parent-child relationships may influence these two subtypes of mastery motivation $(3,5,34)$. Previous studies have found that parent-child relationships were significantly positively linked to mastery motivation in preschool children with CP $(3,21,22,25)$. Waldman-Levi and Erez (25) also suggested that encouraging, supportive parents may promote children's mastery motivation in physical and social environments during an intervention. Moreover, parents' self-efficacy was directly linked to parents' beliefs and parent-child relationships (3), in that parents with high self-efficacy seem to have more positive beliefs and better relationships with their children, thereby potentially supporting their children's greater mastery motivation. Thus, therapists should carefully structure the environment, work with primary caregivers to enhance their self-efficacy, and teach methods of improving parent-child relationships $(3,4)$. Of note is that two studies involving interactions with peers showed less mastery motivation and persistence on tasks in children with CP than children with TD $(23,24)$. Although the evidence is very limited, this may indicate the interaction with other children will result in different social experience on mastery motivation. Future studies may include the interactions with parents or other children as one environmental factor and compare their effects on mastery motivation, which may provide guidelines for future motivational interventions. In addition, adding social elements to object play may be an effective way to induce or maintain children's mastery motivation and increase active interaction styles in play (26). In summary, according to the ICF framework, different functional levels can interact and further influence health. Thus, in further investigations of mastery motivation in preschool children with $\mathrm{CP}$, we suggest that a variety of assessment tools be applied and targeted assessments of relationships between body function, activity, and participation levels be carried out. Clinicians can also discuss training for caregivers in promoting children's autonomy, continuity, and pleasure in daily activities and social and environmental influences on children's motivation.

\section{LIMITATIONS}

The evidence included in this study are only those published in English; other appropriate studies in other languages may have been ignored. In addition, although an extended search was performed by combining various keywords, studies that used different terminology for mastery motivation may have been inadvertently excluded due to the inclusion criteria of direct assessment and explicit discussion of motivation in the studies. Furthermore, in some studies, children with diagnoses other than $\mathrm{CP}$ were included; therefore, the results only covered a small group of preschool children with CP and cannot be generalized to the overall population.

\section{CONCLUSION}

For preschool children, mastery motivation is the driving force behind the desire to explore the surrounding world and is necessary for comprehensive development $(2,4,10)$. According to the ICF model, motivation is a function of the body and can be shaped by environmental and personal factors. Thus, it is essential to identify the optimal physical and social environments for children's participation in activities and to effectively improve children's mastery motivation and therapy outcomes. However, current studies on the mastery motivation of preschool children with $\mathrm{CP}$ are very limited, and the lack of a universal, theorybased definition and assessment methodology makes it difficult to answer key questions about this population. It is therefore suggested that mastery motivation be further investigated with more rigorous study designs, with the objective of identifying ideal activities and environments for preschool children with CP.

\section{AUTHOR CONTRIBUTIONS}

$\mathrm{H}-\mathrm{HH}$ is responsible for the acquisition, analysis, interpretation of data, drafting, and revising the work. T-HS, C-IL, and Y-RC are responsible for the acquisition, analysis, and drafting the work.

\section{REFERENCES}

1. WHO. International Classification of Functioning, Disability and Health (ICF). Geneva: World Health Organization (2001).

2. Morgan GA, MacTurk RH, Hrncir EJ. Mastery motivation: overview, definitions, and conceptual issues. In: MacTurk RH, Morgan GA, eds. Mastery Motivation: Origins Conceptualizations, and Applications. Advances in Applied Developmental Psychology (Vol. 12), Norwood, New Jersey: Ablex Publishing Corporation (1995). p. 1-18.

3. Turner LA, Johnson B. A model of mastery motivation for at-risk preschoolers. J Educ Psychol (2003) 95(3):495-505. doi:10.1037/0022-0663.95.3.495

4. Miller L, Ziviani J, Ware RS, Boyd RN. Mastery motivation: a way of understanding therapy outcomes for children with unilateral cerebral palsy. Disabil Rehabil (2015) 37(16):1439-45. doi:10.3109/09638288.2014.964375

5. Sparks TA, Hunter SK, Backman TL, Morgan GA, Ross RG. Maternal parenting stress and mothers' reports of their infants' mastery motivation. Infant Behav Dev (2012) 35(1):167-73. doi:10.1016/j.infbeh.2011.07.002

6. Miller L, Ziviani J, Ware RS, Boyd RN. Does context matter? Mastery motivation and therapy engagement of children with cerebral palsy. Phys Occup Ther Pediatr (2016) 36(2):155-70. doi:10.3109/01942638.2015.1076556

7. Wang PJ, Morgan GA, Hwang AW, Liao HF. Individualized behavioral assessments and maternal ratings of mastery motivation in mental age-matched toddlers with and without motor delay. Phys Ther (2013) 93(1):79-87. doi:10.2522/ ptj.20120068

8. Wang PJ, Hwang AW, Liao HF, Chen PC, Hsieh WS. The stability of mastery motivation and its relationship with home environment in infants and toddlers. Infant Behav Dev (2011) 34(3):434-42. doi:10.1016/j.infbeh. 2011.04.005 
9. MacTurk RH, Morgan GA, Jennings KD. The assessment of mastery motivation in infants and young children. In: MacTurk RH, Morgan GA, editors. Mastery motivation: Origins, conceptualizations, and applications. Advances in Applied Developmental Psychology (Vol. 12), Norwood, New Jersey: Ablex Publishing Corporation (1995). p. 19-56.

10. Morgan GA, Harmon RJ, Maslin-Cole CA. Mastery motivation: definition and measurement. Early Educ Dev (1990) 1(5):318-39. doi:10.1207/ s15566935eed0105_1

11. Durkin MS, Benedict RE, Christensen D, Dubois LA, Fitzgerald RT, Kirby RS, et al. Prevalence of cerebral palsy among 8-year-old children in 2010 and preliminary evidence of trends in its relationship to low birthweight. Paediatr Perinat Epidemiol (2016) 30(5):496-510. doi:10.1111/ppe.12299

12. Winter S, Autry A, Boyle C, Yeargin-Allsopp M. Trends in the prevalence of cerebral palsy in a population-based study. Pediatrics (2002) 110(6):1220-5. doi:10.1542/peds.110.6.1220

13. Johnson A. Prevalence and characteristics of children with cerebral palsy in Europe. Dev Med Child Neurol (2002) 44(9):633-40. doi:10.1017/ S0012162201002675

14. Stavsky M, Mor O, Mastrolia SA, Greenbaum S, Than NG, Erez O. Cerebral palsy-trends in epidemiology and recent development in prenatal mechanisms of disease, treatment, and prevention. Front Pediatr (2017) 5:21. doi:10.3389/ fped.2017.00021

15. Darrah J, Law MC, Pollock N, Wilson B, Russell DJ, Walter SD, et al. Context therapy: a new intervention approach for children with cerebral palsy. Dev Med Child Neurol (2011) 53(7):615-20. doi:10.1111/j.1469-8749. 2011.03959.x

16. Law M, Darrah J, Pollock N, King G, Rosenbaum P, Russell D, et al. Familycentred functional therapy for children with cerebral palsy: an emerging practice model. Phys Occup Ther Pediatr (1998) 18(1):83-102. doi:10.1080/ J006v18n01_06

17. Tatla SK, Sauve K, Virji-Babul N, Holsti L, Butler C, Van Der Loos HF. Evidence for outcomes of motivational rehabilitation interventions for children and adolescents with cerebral palsy: an American Academy for Cerebral Palsy and Developmental Medicine systematic review. Dev Med Child Neurol (2013) 55(7):593-601. doi:10.1111/dmcn.12147

18. Huang CW, Chen HL, Lin SY, Chen YL, Wang TN. Motivational outcomes of using virtual reality as a therapeutic tool in children with cerebral palsy: a literature review. J Taiwan Occup Ther Assoc (2015) 33(2):187-205.

19. Brown T, Chien CW. Top-down or bottom-up occupational therapy assessment: which way do we go. Br J Occup Ther (2010) 73(3):95. doi:10.4276/030 802210X12682330090334

20. Howick J, Chalmers I, Glasziou P, Greenhalgh T, Heneghan C, Liberati A, et al. The Oxford Levels of Evidence 2. Oxford Centre for Evidence-Based Medicine (2011). Available from: http://www.cebm.net/index.aspx?o=5653

21. Hauser-Cram P. Mastery motivation in toddlers with developmental disabilities. Child Dev (1996) 67(1):236-48. doi:10.2307/1131698

22. Wang PJ, Morgan GA, Hwang AW, Chen LC, Liao HF. Do maternal interactive behaviors correlate with developmental outcomes and mastery motivation in toddlers with and without motor delay? Phys Ther (2014) 94(12):1744-54. doi:10.2522/ptj.20130560

23. Jennings KD, Connors RE, Stegman CE. Does a physical handicap alter the development of mastery motivation during the preschool years? JAm Acad Child Adolesc Psychiatry (1988) 27(3):312-7. doi:10.1097/00004583-198805000-00008

24. Jennings KD, Connors RE, Stegman CE, Sankaranarayan P, Mendelsohn S. Mastery motivation in young preschoolers: effect of a physical handicap and implications for educational programming. ?J Early Interv (1985) 9(2):162-9.

25. Waldman-Levi A, Erez AB. Will environmental interventions affect the level of mastery motivation among children with disabilities? A preliminary study. Occup Ther Int (2015) 22(1):19-27. doi:10.1002/oti.1380

26. Medeiros KF, Cress CJ, Lambert MC. Mastery motivation in children with complex communication needs: longitudinal data analysis. Augment Altern Commun (2016) 32(3):208-18. doi:10.1080/07434618.2016.1179789

27. Liao HF, Morgan G. Relations between maternal interactive behavior and mastery motivation in children with developmental disabilities. Dev Med Child Neurol (2014) 56(3):203-4. doi:10.1111/dmcn.12383

28. Miller L, Ziviani J, Ware RS, Boyd RN. Mastery motivation in children with congenital hemiplegia: individual and environmental associations. Dev Med Child Neurol (2014) 56(3):267-74. doi:10.1111/dmcn.12356

29. Hauser-Cram P, Krauss MW, Warfield ME, Steele A. Congruence and predictive power of mothers' and teachers' ratings of mastery motivation in children with mental retardation. Ment Retard (1997) 35(5):355-63. doi:10.1352/0047-6765(1997)035<0355:CAPPOM > 2.0.CO;2

30. Miller L, Ziviani J, Ware RS, Boyd RN. Mastery motivation as a predictor of occupational performance following upper limb intervention for schoolaged children with congenital hemiplegia. Dev Med Child Neurol (2014) 56(10):976-83. doi:10.1111/dmcn.12471

31. Crocker MD, MacKay-Lyons M, McDonnell E. Forced use of the upper extremity in cerebral palsy: a single-case design. Am JOccup Ther (1997) 51(10):824-33. doi:10.5014/ajot.51.10.824

32. Lin CY, Chang YM. Increase in physical activities in kindergarten children with cerebral palsy by employing MaKey-MaKey-based task systems. Res Dev Disabil (2014) 35(9):1963-9. doi:10.1016/j.ridd.2014.04.028

33. Chen YP, Lee SY, Howard AM. Effect of virtual reality on upper extremity function in children with cerebral palsy: a meta-analysis. Pediatr Phys Ther (2014) 26(3):289-300. doi:10.1097/PEP.0000000000000046

34. Morgan GA, Maslin-Cole CA, Harmon RJ, Busch-Rossnagel NA, Jennings KD, Hauser-Cram $\mathrm{P}$, et al. Parent and teacher perceptions of young children's mastery motivation: assessment and review of research. In: Messer D, editor. Mastery Motivation in Early Childhood: Development, Measurement and Social Processes. London, United Kingdom: Routledge (1993). p. 109-31.

Conflict of Interest Statement: The authors declare that the research was conducted in the absence of any commercial or financial relationships that could be construed as a potential conflict of interest.

Copyright (C) 2017 Huang, Sun, Lin and Chen. This is an open-access article distributed under the terms of the Creative Commons Attribution License (CC BY). The use, distribution or reproduction in other forums is permitted, provided the original author(s) or licensor are credited and that the original publication in this journal is cited, in accordance with accepted academic practice. No use, distribution or reproduction is permitted which does not comply with these terms. 